\title{
Epididymosomes, prostasomes, and liposomes: their roles in mammalian male reproductive physiology
}

\author{
Robert Sullivan and Fabrice Saez ${ }^{1}$ \\ Department of Obstetrics, Gynecology and Reproduction, Université Laval and Reproduction, Mother and Youth \\ Health Research Axes, Research Center, Centre Hospitalier Universitaire de Québec, Pavillon CHUL, 2705 Boul \\ Laurier, Québec, Canada, G1V 4G2 and ${ }^{1}$ Equipe Mécanismes de I'infertilité Post-testiculaire, Clermont Université, \\ Université Blaise Pascal, UMR GReD, Génétique Reproduction and Dévelopement, CNRS 6293, INSERM U1103, \\ Aubière, France
}

Correspondence should be addressed to R Sullivan; Email: robert.sullivan@crchul.ulaval.ca

\begin{abstract}
Mammalian spermatozoa are unique cells in many ways, and the acquisition of their main function, i.e. fertilization capacity, is a multistep process starting in the male gonad and ending near the female egg for the few cells reaching this point. Owing to the unique character of this cell, the molecular pathways necessary to achieve its maturation also show some specific characteristics. One of the most striking specificities of the spermatozoon is that its DNA is highly compacted after the replacement of histones by protamines, making the classical processes of transcription and translation impossible. The sperm cells are thus totally dependent on their extracellular environment for their protection against oxidative stress, for example, or for the molecular changes occurring during the transit of the epididymis; the first organ in which post-testicular maturation takes place. The molecular mechanisms underlying sperm maturation are still largely unknown, but it has been shown in the past three decades that extracellular vesicles secreted by the male reproductive tract are involved in this process. This review will examine the roles played by two types of naturally occurring extracellular vesicles, epididymosomes and prostasomes, secreted by the epididymis and the prostate respectively. We will also describe how the use of artificial vesicles, liposomes, contributed to the study of male reproductive physiology.

Reproduction (2013) 146 R21-R35
\end{abstract}

\section{Introduction}

Anatomically, the male reproductive tract shows great variability between vertebrate species. This is also true within the mammalian species: great penis variability, absence of seminal vesicles in dogs and tomcats, an almost undifferentiated prostate in bulls, etc. During their journey in both male and female reproductive tracts, spermatozoa encounter different extracellular milieu that modulate their metabolism, their membrane and intracellular structures, and their biochemical composition. The end product is a fully functional male gamete ready to encounter the different barriers surrounding the oocyte. The interaction between spermatozoa and the different intraluminal milieux has raised interest for decades, in particular, the sperm maturational process during epididymal transit. At ejaculation, spermatozoa are mixed with secretions of male tract accessory glands. Functions of this complex biological fluid in sperm physiology are also of great interest for reproductive biologists.

There is growing interest in the extracellular vesicles secreted by different cell types that target other tissues or cells in the body. Depending on their properties and mode of secretion, they have been classified as exosomes, ectosomes, microvesicles, apoptotic vesicles, and other extracellular vesicles (Bobrie et al. 2011, Thery 2011). Extracellular vesicles are also secreted by the male reproductive tract, especially by the epididymis and the prostate; they have been named epididymosomes and prostasomes respectively. The role of these membrane vesicles in sperm physiology is reviewed. Liposomes are artificial lipid vesicles used to optimize cryopreservation of semen and also to modulate different aspects of male reproductive functions. The usefulness of liposomes in male reproductive biology is also reviewed.

\section{Epididymosomes}

\section{The epididymis}

One of the most amazing structures of the male reproductive tract is the epididymis, which is present in all vertebrate species practicing internal fertilization. In mammals, the epididymis (in Greek, epi for 'on' and 
didumoi for 'testis') is a long convoluted tubule connecting the rete testis, from which differentiated spermatozoa leave the testicles, to the vas deferens, starting point of the sperm ejaculation journey. The length of the unraveled epididymis varies from one species to another; it can be as long as 40 and $80 \mathrm{~m}$ in bulls and stallions respectively. At human scale, the epididymal journey of bovine sperm represents a trip of $\sim 2750 \mathrm{~km}$. Why so long a transit for the differentiated spermatozoa to reach the ejaculatory duct?

Considering that mating is not always synchronized with ovulation and that the epididymis is the signature of the male tract of vertebrates practicing internal fertilization, the epididymis is probably involved in sperm heterogeneity. In mammals in particular, sperm will be maintained in a quiescent state for various periods of time in the female tract, creating a sperm reservoir. These periods can be of $24-48 \mathrm{~h}$ as in humans and as long as $4-5$ months in bats. At different periods of time, some spermatozoa will escape from the sperm reservoir and will complete their transit at the fertilization site, increasing in this way the window of fertility for a given ejaculate. This means that a heterologous population of male gametes will be deposited in the female tract. The epididymis is also known to be involved in sperm transport in the male tract, to act as sperm storage in its distal part, and to be the site of sperm maturation. This means that the spermatozoon entering the epididymis is unable to fertilize and remains immotile. Under androgen action and other poorly defined intraluminal factors, the epididymis will orchestrate morphological and biochemical modifications of the male gamete; these changes being collectively called sperm maturation.

The epididymis is classically divided into three segments: the proximal caput, the elongated corpus, and the distal cauda. In rodents, a proximal segment with histological characteristics distinct from the caput segment has been named the initial segment. The epididymis is highly differentiated and each segment has its own pattern of gene expression that has been well described in mice (Johnston et al. 2005), rats (Johnston et al. 2007), and humans (Thimon et al. 2007). The epididymal tubule is formed by a secretory pseudo-stratified epithelium delimitating the intraluminal compartment. The epididymal epithelium is characterized by a unique set of tight junctions that allow an intraluminal milieu with a composition of electrolytes and macromolecules that is different from that of the circulating body fluids. The protein composition of the intraluminal fluid is distinct from one segment to the other. These proteins, by interacting with the male gametes, orchestrate biochemical modifications of spermatozoa in a sequential manner resulting in a fully functional gamete.

The proteins secreted in the intraluminal compartment of the epididymis interact with spermatozoa; some of them modify surface proteins or other plasma membrane components, others are incorporated into the sperm subcellular domains. While some newly acquired proteins behave as coating proteins, meaning that they are maintained on the sperm surface by electrostatic interactions, others behave as integral membrane proteins (Cooper 1998). Some extracellular proteins, such as macrophage migration inhibitory factor (MIF), are even able to cross the sperm plasma membrane and to incorporate themselves in intracellular structures and become associated with flagellar dense fibers (Eickhoff et al. 2001, 2006). How these proteins are acquired by spermatozoa during maturation in the epididymis is a question that has intrigued reproductive biologists since the 1970s.

Owing to high input of androgens from testis and to endogenous $5 \alpha$-reductase activity, the epididymal epithelium is very active in protein synthesis and secretion (Robaire \& Viger 1995). Epididymal protein synthesis and secretion is essential for sperm maturation, especially for the acquisition of the ability to bind the zona pellucida (ZP) surrounding the oocyte. The merocrine pathway of secretion is the classical way for an epithelium to secrete proteins. The signal peptide of elongating translational product targets the protein to the endoplasmic reticulum. The protein is post-translationally modified in the Golgi apparatus from which secretory vesicles are generated that will liberate the protein in the extracellular milieu by exocytosis. In the 1980s, many cDNA-encoding proteins secreted in the intraluminal compartment of the epididymis and potentially involved in sperm maturation have been sequenced (reviewed by Kirchhoff (1999)). It became evident that some of these secreted proteins lack a signal peptide. More intriguing was the ascertainment that some of these secreted proteins were acquired by spermatozoa during epididymal transit by a glycosylphosphatidylinositol (GPI) anchor. Knowing that the acquisition of a GPI anchor is a posttranslational modification occurring in the Golgi apparatus and that a membrane protein with a GPI anchor is acquired by the plasma membrane when secretory vesicles containing the protein fuse with the cell plasma membrane, it thus becomes apparent that an alternative pathway of secretion must exist in the epididymis.

\section{Apocrine secretion of epididymosomes}

Apocrine secretion was first described by the German histologist P Schiefferdecker in 1922. It consists of blebbing at the apical pole of the secretory cells. The blebs detach from the cell and their content is released in the extracellular compartment when the blebs disintegrate (Nickel 2003). Although controversial, apocrine secretion is considered to be the major secretory pathway of the prostate. It seems that the reproductive tract extensively uses the apocrine secretion pathway, as 
it has been described in the prostate, seminal vesicles (Aumuller et al. 1997), coagulating gland (Groos et al. 1999), vas deferens (Manin et al. 1995), epididymis (Hermo \& Jacks 2002, Rejraji et al. 2006), and, in females, in the uterus (Griffiths et al. 2008).

In the epididymis, blebs at the apical pole of principal cells have been well described at the ultrastructural level (Hermo \& Jacks 2002, Rejraji et al. 2006). Their contents appear to be segregated; only free ribosomes, endoplasmic reticulum cisternae, and small membrane vesicles are visualized. The presence of these $20 \mathrm{~nm}$ diameter vesicles in the apical cytoplasm of cells forming blebs as well as in the intraluminal compartment suggests that they are liberated in the epididymal lumen once the blebs detach from the cells and disintegrate in the extracellular compartment. First described by Jones et al. (1978) in boar and Davis (1980) in rabbit, they were thought to be an artifact due to poor tissue fixation (Aumuller et al. 1999). Yanagimachi et al. (1985) have nicely revisited the association of small membrane vesicles with epididymal spermatozoa in Chinese hamsters. In this species, 20-100 nm vesicles appear on the sperm surface in the distal caput epididymidis and start to decrease in number in the cauda epididymidis. They were found to bind only to the sperm region covering the acrosome. Knowing that these vesicles are rich in cholesterol, it was hypothesized that they could be involved in cholesterol transfer to the sperm membrane in order to stabilize it (Davis 1980). At the ultrastructural level, there was, however, no evidence of fusion of these vesicles with the spermatozoa during epididymal transit (Yanagimachi et al. 1985). Since these pioneer works, the presence of small membrane vesicles, or epididymosomes, has been described in hamsters (Legare et al. 1999), rats (Fornes et al. 1995a, Grimalt et al. 2000), mice (Rejraji et al. 2006, Griffiths et al. 2008), rams (Ecroyd et al. 2004, Gatti et al. 2004), bovines (Frenette \& Sullivan 2001, Frenette et al. 2002), and humans (Thimon et al. 2008b). The protein composition of epididymosomes has been shown to be distinct from the unfractionated epididymal fluid (Frenette et al. 2002, Gatti et al. 2004). In a given epididymal segment, epididymosomes contain a heterologous population of vesicles with different protein compositions that can be fractionated according to their relative density (Fornes et al. 1995b, Frenette et al. 2010). In bovines, one subpopulation of vesicles shares characteristics with exosomes (J Caballero, G Frenette, C Belleannee and R Sullivan, unpublished observations).

\section{Epididymosome composition}

The lipid composition of epididymosomes varies along the epididymis. In bovine (Girouard et al. 2011) as in murine (Rejraji et al. 2006) species, the cholesterol: phospholipid ratio of epididymosomes increases by 1.5-fold from caput to cauda segments. In mice, epididymosomes are enriched in sphingomyelin and polyunsaturated membranous fatty acids, especially in arachidonic acids. Sphingomyelin concentration in epididymosomes increases during epididymal transit and represents half of the phospholipids in the caudal epididymosomes in murine cauda (Rejraji et al. 2006). Phosphatidylinositol, phosphatidylcholine and sphingomyelin also decrease along the epididymis (Girouard et al. 2011). Interestingly, cholesterol and sphingomyelin are concentrated in lipid rafts, also named detergentresistant membrane (DRM), at least in cauda epididymosomes in bulls.

The mammalian sperm surface is highly organized in different sub-domains. Surface proteins, including those acquired during epididymal transit, are located in specific regions of the sperm depending on their functions (Cooper 1998, Jones 1998). How epididymal secreted proteins are targeted to a specific plasma membrane sub-domain, as $\mathrm{P} 26 \mathrm{~h} / \mathrm{P} 25 \mathrm{~b}$ is targeted to the plasma membrane covering the acrosome or macrophage MIF is incorporated into dense fibers once transferred to the intracellular compartment, remains to be determined. Protein transfer from epididymosomes to spermatozoa must thus occur in a way that newly acquired proteins are segregated in the sub-domain relevant to their functions. DRM domains, or rafts, are enriched in cholesterol and sphingomyelin. They segregate proteins, especially those with a GPI anchor. They are involved in signaling pathways and protein and lipid trafficking (Simons \& Ikonen 1997, Sengupta et al. 2007). Rafts are present in bovine epididymosomes and $\mathrm{P} 25 \mathrm{~b}$ is exclusively associated with these sub-membrane domains. Interestingly, this protein is transferred to raft domains of maturing spermatozoa. Other proteins such as MIF and aldose reductase present in epididymosomes are not associated with their raft domains. When epididymosomes are treated with proteolytic enzymes, P25b, by opposition to MIF and aldose reductase, is degraded, indicating that $\mathrm{P} 25 \mathrm{~b}$ is located at the surface of epididymosomes. By opposition, MIF and aldose reductase are embedded in the internal structure of epididymosomes (Girouard et al. 2009). The transfer of specific proteins between raft domains may be used to target epididymal secreted proteins to a specific sub-compartment of the sperm membrane.

Protein composition of epididymosomes differs from fluids or spermatozoa collected in the same segment of the epididymis, at least in rams (Gatti et al. 2004, 2005) and bulls (Frenette et al. 2002, 2003). In 2011, Girouard et al. (2011) described the proteome of epididymosomes collected in the caput and cauda epididymidis in bovine. Five hundred and fifty five and 438 proteins were identified in caput and cauda epididymosomes respectively, 231 proteins being common to both types of epididymosomes. Interestingly, Rab and SNARE proteins known to be involved in vesicle trafficking and fusion were found in both populations of epididymal 
membrane vesicles. Proteins proposed to be involved in sperm-egg interaction and motility as well as proteins involved in remodeling of sperm components or potentially involved in sperm protection and elimination were shown to be associated with epididymosomes. Globally, glycan-modifying enzymes were part of the caput epididymosome signatures. Thimon and colleagues used liquid chromatography-quadrupole time of flight technology to describe the proteome of human cauda epididymosomes collected from the vas deferens during surgical vasectomy reversal (Thimon et al. 2008a, $2008 b$ ). These results were analyzed in parallel to transcriptomes of caput, corpus, and cauda epididymidis of normal and vasectomized humans. The major conclusion from this study is that epididymosomes transit along the epididymis in humans and that vesicles collected distally represent a mixed population of vesicles secreted all along the epididymis. How these results can be transposed to animal models remains to be determined (Thimon et al. 2007, 2008a). Some proteins of ram epididymosomes have been identified by mass spectrometry analysis of selected protein spots separated by two-dimensional gel electrophoresis such as dipeptidyl peptidase, lactadherin, and vacuolar ATPase (Gatti et al. 2005). The protein composition of epididymosomes is complex and varied along the epididymis.

\section{Functions of epididymosomes in sperm physiology}

In bulls, aldose reductase (Frenette et al. 2003, 2004) as well as the other enzyme of the polyol pathway, sorbitol dehydrogenase, has been shown to be associated with epididymosomes, suggesting that these vesicles may modulate sperm motility during epididymal transit (Frenette et al. 2004). MIF has also been identified as a constituent of epididymosomes (Frenette et al. 2003, Eickhoff et al. 2004, 2006). MIF is a classical T-cell cytokine also expressed in different cell systems where it plays various functions. In spermatozoa, it is associated with sperm dense fibers (Eickhoff et al. 2006) where it could be involved in $\mathrm{Zn}^{++}$elimination by affecting free sulfhydryl groups in sperm flagellum (Eickhoff et al. 2004, Frenette et al. 2005), a phenomenon known to occur during the maturational process. Thus, epididymosomes appear to modulate sperm motility during epididymal maturation. Liprin $\alpha 3$ (Joshi et al. 2012), a protein involved in the acrosome reaction (AR), and the kinase cSrc (Krapf et al. 2012) are two other proteins associated with epididymosomes, suggesting that these vesicles may be involved in different modifications undergone by ejaculated sperm before fertilization.

Glutathione peroxidase 5 (GPX5) is another protein associated with epididymosomes in murine species (Rejraji et al. 2002). GPX5 is a seleno-independent GPX protecting sperm from oxidative stress, including preserving their DNA integrity (Chabory et al. 2009). Epididymosomes thus appear to play a role not only in sperm protection but also in elimination of defective sperm cells as illustrated by the association of ubiquitin (Fraile et al. 1996, Sutovsky et al. 2001) and epididymal sperm binding protein 1 (ELSPBP1) to these small membrane vesicles (D'Amours et al. 2012a). Since ubiquitin is involved in enzymatic degradation of proteins by proteasome, it is hypothesized to be involved in elimination of defective spermatozoa during the epididymal transit. ELSPBP1 is transferred in a $\mathrm{Zn}^{++}$ dependent manner from epididymosomes to spermatozoa during epididymal maturation in bovines ( $\mathrm{D}^{\prime}$ Amours et al. 2012b). Interestingly, ELSPBP1 binds to a subpopulation of spermatozoa already dead at ejaculation. This epididymal protein acquired by the maturing spermatozoa through interactions with epididymosomes may 'tag' sperm cells that must be eliminated or be involved in a mechanism protecting live spermatozoa against deleterious molecules liberated by dying ones (D'Amours et al. 2012a).

Different proteins known to be acquired by mammalian spermatozoa during epididymal transit behave as integral membrane proteins, some of them being GPIanchored (Cooper 1998). One of the most intriguing is human epididymal protein 5 (HE5) identified by differential screening of human epididymal cDNAs (Kirchhoff 1996). HE5, which is in fact CD52, is a highly glycosylated small peptide GPI-anchored to the cell surface (Kirchhoff 1996, Kirchhoff \& Hale 1996). Different hypotheses have been considered to explain the transfer of epididymal secreted protein with a GPI anchor to the sperm surface. One of the proposed mechanisms suggests that GPI-enriched vesicles 'shed' from the principal cells of the epididymal epithelium could be involved in this transfer (Kirchhoff \& Hale 1996, Kirchhoff 1998). In hamsters, P26h is a protein secreted by the epididymis, acquired by transiting spermatozoa, and involved in sperm-ZP binding (reviewed by Sullivan (1999)). P26h is another protein GPI-anchored to the sperm plasma membrane. While hamster spermatozoa accumulate P26h during epididymal transit, the amount of P26h associated with epididymosomes decreases along the excurrent duct, suggesting that epididymosomes are involved in acquisition of this protein during sperm maturation (Legare et al. 1999). In bulls, P25b, the P26h ortholog, is also GPI-anchored to spermatozoa. In 2001, we published the first co-incubation experiments showing that epididymosomes were able to transfer this protein to spermatozoa collected in the bovine epididymis (Frenette \& Sullivan 2001). Subsequent co-incubation experiments using bovine material show that a subset of selected proteins associated with epididymosomes is transferred to defined domains of the sperm surface. This transfer is temperature-and $\mathrm{pH}$-dependent being more efficient at $\mathrm{pH}$ 6.0-6.5, which is the physiological $\mathrm{pH}$ of the intraluminal epididymal compartment. Interestingly, whereas $\mathrm{Ca}^{++}$and $\mathrm{Mg}^{++}$have no effect on in vitro 
protein transfer from epididymosomes to spermatozoa, $\mathrm{Zn}^{++}$potentiates the amount of proteins transferred to spermatozoa (Frenette et al. 2002). It is noteworthy that the epididymis is characterized by high $\mathrm{Zn}^{++}$ concentrations (Mawson \& Fischer 1951).

Sperm adhesion molecule 1 (SPAM1, previously known as $\mathrm{PH}-20$ ) is another protein GPI anchored to spermatozoa in different mammalian species; different roles in fertilization have been proposed for this protein. Epididymal and testicular forms of SPAM1 have been described, the epididymal form being found in both the soluble and the epididymosome fractions of the intraluminal compartment (Martin-DeLeon 2006, Griffiths et al. 2008). As P26h/P25b, SPAM1 is secreted by apocrine secretion of epididymal epithelial cells and is GPI anchored to epididymosomes (Martin-DeLeon 2006, Griffiths et al. 2008). Glioma pathogenesis-related protein 1 (GLIPR1L1) belonging to the CAP family (cysteine-rich secretory proteins, antigen 5, pathogenesis-related 1) (reviewed by Gibbs et al. (2008)) is expressed in testis and in epididymis; some evidence suggests that it is GPI-anchored to epididymosomes. It has been proposed that GLIPR1L1 plays a role in fertilization in murine (Gibbs et al. 2010) and bovine species (Caballero et al. 2012).

Whereas epididymosomes have been shown to be involved in the acquisition by spermatozoa of GPI-anchored proteins during epididymal transit, other proteins are associated in a different way with these membrane vesicles. ADAM7 is a member of transmembrane protein family, 'a disintegrin and metalloprotease' exclusively expressed in the epididymis (Oh et al. 2005). The amount of ADAM7 expression being dependent on ADAM2 and ADAM3A (ADAM3), these three proteins have been proposed to be involved in fertilization in murine species. ADAM7 is undetectable in the soluble fraction of epididymal fluid, being associated with epididymosomes as an integral membrane protein. Once transferred to spermatozoa during the epididymal journey, ADAM7 has biochemical characteristics of an integral membrane protein, suggesting that epididymosome-to-sperm transfer may involve fusion between sperm and these membrane vesicles (Oh et al. 2009). Methylmalonate-semialdehyde dehydrogenase (MMSDH) is an epididymal sperm protein expressed under androgen stimulation. It behaves as both a peripheral and an integral protein when sperm are submitted to different physicochemical treatments and is transferred from epididymosomes to testicular spermatozoa in in vitro co-incubation experiments (Suryawanshi et al. 2012). Thus, epididymal proteins associated with epididymosomes and spermatozoa are anchored to biological membranes by different mechanisms. Considering the complexity of proteins acquired by spermatozoa in the presence of epididymosomes, many mechanisms of transfer may be involved.
Epididymosomes secreted via the apocrine pathway play a major role in mammalian sperm maturation (Table 1). Molecular composition of these membrane vesicles differs from that of the soluble fraction of the epididymal intraluminal compartment allowing different mechanisms of interaction with the maturing spermatozoa in order to generate fully functional male gametes. The biochemical mechanisms underlying macromolecule transfer from epididymosomes to maturing spermatozoa are elusive and subjects of current research.

\section{Prostasomes}

At ejaculation, cauda epididymal spermatozoa are mixed with secretions of the reproductive tract accessory glands. Whereas functions of seminal plasma are poorly understood, the presence of small membrane vesicles has been known for more than three decades (Ronquist \& Hedstrom 1977). Owing to scarcity of human epididymal tissues, epididymosomes have been studied using large and laboratory mammalian species. In contrast, ontogeny and functions of membrane vesicles in the seminal plasma have been almost exclusively studied in humans. Many excellent reviews have been recently published on this topic; for more information on these vesicles, readers may refer to Burden et al. (2006) and Ronquist (2012). Comparative properties of epididymosomes and prostasomes are presented in Fig. 1.

Using antibodies raised against membrane vesicles prepared from seminal plasma, immunohistological studies showed that they originate from acinar cells of prostate in humans; they thus have been named 'prostasomes'. Even though epididymosomes from the cauda epididymidis are probably mixed with accessory glands' secretions at ejaculation, they represent a very minor proportion of vesicles in seminal plasma, at least in bovines (Frenette et al. 2006). As epididymosomes, prostasomes form a heterologous population of multilayered lipid membrane with regard to size and appearance at the electron microscopic level (Aalberts et al. 2012a). While epididymosomes are a product of apocrine secretion by epididymal epithelial cells, prostasomes are contained in larger vesicles in acinar cells, similar to multivesicular bodies (MVB). Prostasomes are secreted when the MVB fuse with the plasma membrane of acinar cells. Exocytotics of MVB is similar to the secretion pathway of exosomes known to be membrane vesicles targeting other cells in the body. In fact, prostasomes contain CD9, a ubiquitous marker of exosomes (Aalberts et al. 2012b). Prostasomes have a high $\mathrm{CH}$ :phospholipid ratio close to 2:1 and sphingomyelin represents half of their phospholipids (Arienti et al. 1999). This unusual lipid composition confers particular biophysical characteristics on these vesicles. 
Table 1 Proteins associated with epididymosomes ${ }^{a}$. Proteins from epididymosomes with known or proposed functions once transferred to spermatozoa during maturation.

\begin{tabular}{|c|c|c|c|c|}
\hline Name & Abbreviation & Functions & Particularities & References \\
\hline $\begin{array}{l}\text { Macrophage migration inhibi- } \\
\text { tory factor }\end{array}$ & MIF & $\begin{array}{l}\text { Associated with sperm dense } \\
\text { fibers: involved in motility }\end{array}$ & $\begin{array}{l}\text { Chelation of } \mathrm{Zn} \text {; disulfide-bound } \\
\text { formation }\end{array}$ & $\begin{array}{l}\text { Eickhoff et al. }(2004,2006) \text { and } \\
\text { Frenette et al. }(2002,2003, \\
\text { 2004, 2005, 2006, 2010) }\end{array}$ \\
\hline Liprin $\alpha 3$ & Ppfia3 & Acrosome reaction & $\begin{array}{l}\text { Estrogen-responsive element in } \\
\text { the } 5^{\prime} \text { UTR }\end{array}$ & Joshi et al. (2012) \\
\hline Kinases cSrc & cSrc & $\begin{array}{l}\text { Signaling cascade of capacita- } \\
\text { tion }\end{array}$ & $\begin{array}{l}\text { Essential in cauda epididymal } \\
\text { development }\end{array}$ & Krapf et al. (2012) \\
\hline Glutathione peroxidase 5 & GPX5 & $\begin{array}{l}\text { Protection against oxidative } \\
\text { stress (DNA integrity) }\end{array}$ & Seleno-independent GPX & Chabory et al. (2009) \\
\hline Ubiquitin & UBC & $\begin{array}{l}\text { Elimination of defective sper- } \\
\text { matozoa }\end{array}$ & Involved in proteasome activity & $\begin{array}{l}\text { Fraile et al. (1996) and Sutovsky } \\
\text { et al. (2001) }\end{array}$ \\
\hline $\begin{array}{l}\text { Epididymal sperm binding } \\
\text { protein } 5\end{array}$ & CD52 (HE5) & $\begin{array}{l}\text { Protection against immune } \\
\text { response }\end{array}$ & $\begin{array}{l}\text { Highly glycosylated GPI } \\
\text { anchored to sperm surface }\end{array}$ & $\begin{array}{l}\text { Kirchhoff \& Hale (1996), for } \\
\text { review }\end{array}$ \\
\hline $\begin{array}{l}\text { Epididymal sperm binding } \\
\text { protein } 1\end{array}$ & ELSPBP1 & $\begin{array}{l}\text { Elimination of defective sper- } \\
\text { matozoa }\end{array}$ & $\begin{array}{l}\text { Zn-dependent transfer from epi- } \\
\text { didymosomes to spermatozoa }\end{array}$ & D'Amours et al. (2012a, 2012b) \\
\hline P26h (hamsters), P25b (bovine) & $\mathrm{P} 26 \mathrm{~h} / \mathrm{P} 25 \mathrm{~b}$ & $\begin{array}{l}\text { Sperm-zona pellucida } \\
\text { interaction }\end{array}$ & GPI-anchored to sperm surface & $\begin{array}{l}\text { Legare et al. (1999) and Frenette } \\
\quad \text { \& Sullivan (2001) }\end{array}$ \\
\hline Sperm adhesion molecule 1 & SPAM1 $(\mathrm{PH}-20)$ & Different roles in fertilization & GPI-anchored to sperm surface & $\begin{array}{l}\text { Martin-DeLeon (2006) and } \\
\text { Griffiths et al. (2008) }\end{array}$ \\
\hline $\begin{array}{l}\text { Glioma pathogenesis-related } \\
\text { protein } 1\end{array}$ & GLIPR1L1 & Roles in fertilization & $\begin{array}{l}\text { Belongs to the CAP family, GPI- } \\
\text { anchored to sperm surface }\end{array}$ & $\begin{array}{l}\text { Caballero et al. (2012) and } \\
\text { Gibbs et al. (2010) }\end{array}$ \\
\hline A desintegrin metalloproteases & $\begin{array}{l}\text { ADAM2, } \\
\text { ADAM3, } \\
\text { ADAM7 }\end{array}$ & Involved in fertilization & $\begin{array}{l}\text { Behave as integral membrane } \\
\text { proteins once transferred to } \\
\text { sperm }\end{array}$ & Oh et al. (2005) \\
\hline $\begin{array}{l}\text { Methylmalonate-semialdehyde } \\
\text { dehydrogenase }\end{array}$ & MMSDH & Unknown & $\begin{array}{l}\text { Behave as peripheral and inte- } \\
\text { gral membrane protein once } \\
\text { transferred to sperm }\end{array}$ & Suryawanshi et al. (2012) \\
\hline
\end{tabular}

aProteomes of ram epididymosomes (exosomes-like), bovine caput, and cauda epididymosomes and of human 'epididymosomes' collected from the proximal vas deferens during vasectomy procedures have been published by Gatti et al. (2005), Thimon et al. (2008a, 2008b) and Girouard et al. (2011) respectively.

Two studies on prostasome proteomes, one in 2003 (Utleg et al. 2003) and the other in 2009 (Poliakov et al. 2009) reported 139 and 440 different proteins respectively. Up to one third of the identified proteins are prostasomal enzymes, some of which are GPI-anchored to the membrane vesicles. Interestingly, prostasomes are enriched in divalent cations such as calcium, zinc, and magnesium. It has been hypothesized that prostasomes modulate divalent cation concentrations in the vicinities of spermatozoa in order to modulate flagellar motility (Fabiani et al. 1995) or that they stimulate a well-characterized prostasomal ATPase activity (Ronquist et al. 1978). Prostasomes also contain DNA fragments that are transferred to spermatozoa; the significance of this observation, however, remains to be determined (Ronquist 2012).

Prostasomes have been proposed to protect spermatozoa against immune response in the female reproductive tract by modulating the complement pathway and by inhibiting monocyte and neutrophil phagocytosis and lymphocyte proliferation. They also have antioxidant and antibacterial properties, conferring supplemental protection to ejaculated spermatozoa (reviewed by Saez et al. (2003) and Burden et al. (2006)). Prostasomes also modulate many physiological parameters of ejaculated spermatozoa. Even though prostasomes fused with spermatozoa at $\mathrm{pH} 4-5$, a nonphysiological condition (Arienti et al. 1997), it is believed that interaction of these membrane vesicles with spermatozoa is hydrophobic in nature (Ronquist et al. 1990). Whilst the mechanisms of prostasomesspermatozoa interactions remain to be elucidated, there is plenty of evidence in favour of a role of these membrane vesicles in sperm physiology.

The usual way of studying prostasome functions is to incubate washed ejaculated spermatozoa with membrane vesicles purified from the seminal plasma by serial centrifugations followed by gel filtration. It thus appears that spermatozoa that have already been in contact with prostasomes are still able to interact with them. Prostasome suspensions promote the progressive motility of spermatozoa in humans (Fabiani et al. 1995). The transfer of calcium signaling proteins from prostasomes to spermatozoa seems to be the mechanism involved in sperm motility improvement. Once in the female genital tract, spermatozoa have to undergo capacitation, a prerequisite of the AR. An efflux of sperm membrane cholesterol is one of the first events leading to capacitation. The seminal plasma is notoriously known to inhibit capacitation. Prostasomes being rich in cholesterol, these vesicles are probably responsible for this inhibitory activity (Pons-Rejraji et al. 2011). Prostasomes thus appear to play protective roles for ejaculated spermatozoa and modulate some sperm physiological parameters such as forward motility and capacitation. 


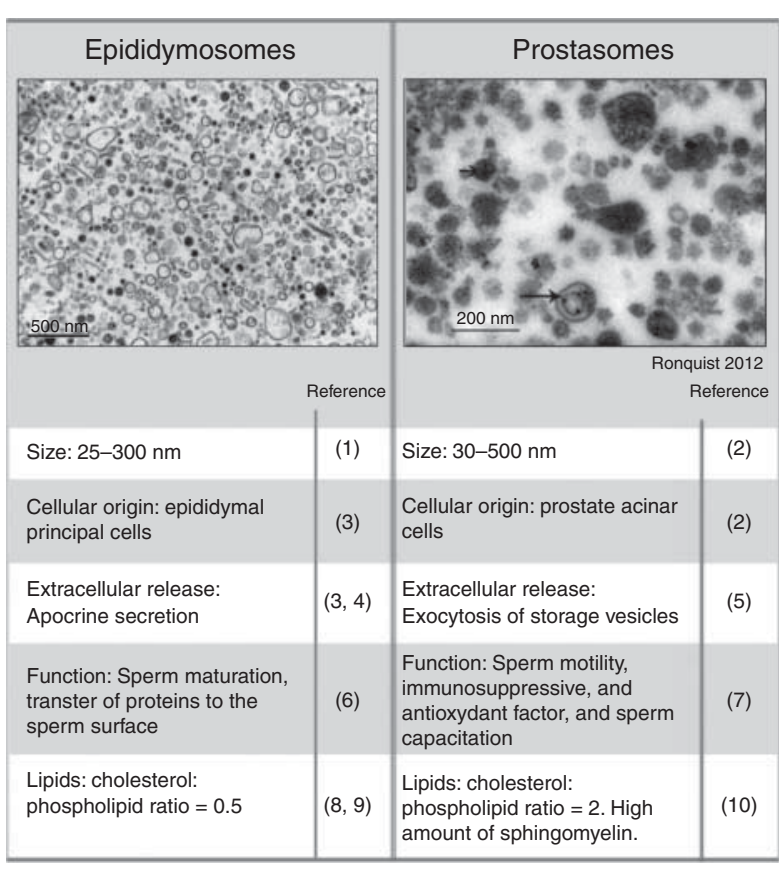

Figure 1 Comparison between epididymosomes and prostasomes. (1) Saez et al. (2003), (2) Ronquist \& Brody (1985), (3) Hermo \& Jacks (2002), (4) Aumuller et al. (1997), (5) Sahlen et al. (2002), (6) for review, Sullivan et al. (2005), (7) for review, Ronquist (2012), (8) Rejraji et al. (2006), (9) Girouard et al. (2011), and (10) Arvidson et al. (1989). Right panel reproduced with permission from Ronquist (2012), copyright 2012 John Wiley and Sons, licence number 3121490381901.

\section{Liposomes}

While extracellular vesicles such as epididymosomes and prostasomes are involved in post-testicular sperm processing and protection, artificial lipid vesicles have been used to study the importance of different classes of lipids for sperm-fertilizing capacity. The principal applications of liposomes are i) their protective effect on sperm function after cryopreservation; ii) their use as vehicles for the incorporation of foreign material (DNA or ATP); iii) the regulation of sperm function by lipids, at the steps of capacitation, gamete interaction, and/or fusion and AR; and iv) the study of membrane ion channels by patch-clamp methodology, using spermderived liposomes.

\section{Sperm cryopreservation}

Sperm cryopreservation is a routine procedure used for human fertility preservation as well as for agricultural purposes, mainly to favour the efficiency of reproduction in breeding species. The main problem related to sperm cryopreservation is limiting the freezing-thawinginduced damage likely to impair sperm viability and functions. A great proportion of this damage is related to membrane-associated loss of function, due to the relative resistance of this cellular structure to temperature and physical state changes of its immediate environment.
Egg yolk has been widely used as an additive in cryoprotective media, as early as 1940 (Philips \& Lardy), but for obvious sanitary and reproducibility reasons, this cannot be used anymore. The phospholipid moieties present in egg yolk have previously been characterized as conferring the cryoprotective properties (Quinn et al. 1980). Considering this, attempts have been made to substitute egg yolk with defined lipids, among which liposomes are made from known molecules. This work has been conducted on several species, i.e. bulls, rams, boars, and stallions. One of the first reports showing some protective effects of artificial liposomes on sperm functions after freezing and thawing was made on bull spermatozoa (Graham et al. 1987). These authors demonstrated that only phosphatidylserine/cholesterol liposomes were as protective as egg yolk in preserving the percentage of progressively motile spermatozoa after freezing and thawing. This result was comforted by a study showing that dioleoylphosphatidylcholine (DOPC) vesicles combined with BSA could also protect sperm membrane integrity at a level similar to egg yolk (De Leeuw et al. 1993). In this work, the authors showed that membrane-stabilizing agents were more efficient than ice-preventing agents (such as glycerol or sucrose) in the sperm cryoprotection.

A critical point of the freezing process resides in the chilling phase before freezing, as cells will undergo phase transition of their membranes, changing from a liquidcrystalline state to a gel phase. The lipid phase transition temperature $(\mathrm{Tm})$ characterizing this step is highly dependent on the lipid composition of the membranes. The effect of either egg-phosphatidylcholine (EPC) or dipalmitoylphosphatidylcholine (DPPC) liposomes was studied on the Tm and the membrane integrity of chilling bovine sperm (Zeron et al. 2002). The EPC-treated sperm had a greater resistance to chilling and showed a decline in membrane integrity only at the lowest temperatures investigated whereas the DPPC-treated sperm group was injured at all temperatures tested. The Tm was less than $4{ }^{\circ} \mathrm{C}$ for the EPC-treated group (vs $13{ }^{\circ} \mathrm{C}$ for the control group) and was of $23^{\circ} \mathrm{C}$ for the DPPC-treated sperm, showing here again the high protective effect of egg yolk lipids. This result is in accordance with the fact that saturated fatty acids (C16:0 in DPPC liposomes) increase the Tm of biological membranes. A comparison of the protective effects of liposomes made from saturated lipids vs unsaturated lipids or EPC was recently conducted (Ropke et al. 2011). The highest post-thaw survival rates (estimated by progressive motility and acrosome- and plasma membrane-intact cells) were obtained with DOPC:DOPG liposomes (dioleoylphosphocholine 18:1; dioleoylphosphoglycerol 18:1). Interestingly, the lipid phase state of the liposomes was not the decisive factor for their cryoprotective action, as dimyristoylphosphocholine (DMPC, in a gel phase at $4^{\circ} \mathrm{C}$ ) and DOPC (fluid phase at $4{ }^{\circ} \mathrm{C}$ ) had similar effects. The underlying mechanisms of how liposomes stabilize cells 
during freezing or thawing are still poorly understood, but a possible explanation could be that liposomes modify sperm membranes by exchanging lipids and $\mathrm{CH}$, thus modifying membrane physical properties at reduced temperatures. This hypothesis is supported by a recent study demonstrating that $\mathrm{CH}$ or cholestanol delivery to bull sperm membranes before cryopreservation, using cyclodextrin as a vehicle, improved cell survival, measured by the percentage of progressive motility (Moraes et al. 2010).

The effects of lipid additives on sperm membrane integrity and/or survival have also been studied in other species. In rams, the addition of phospholipid dispersions (EPC and DMPC) to washed spermatozoa provided immediate protection against cold shock, measured by motility preservation (Quinn et al. 1980). The motility and acrosomal integrity of spermatozoa submitted to a cold shock $\left(5^{\circ} \mathrm{C}\right)$ were preserved by phosphatidylcholine:cholesterol liposomes (Holt \& North 1988). The cryoprotective properties of cholesterol and phosphatidylcholine were confirmed, when added as single agents in the medium, with respect to cell membrane integrity of frozen-thawed sperm cells (Ollero et al. 1996). Boar spermatozoa incubated with liposomes made from a complex mixture of selected phospholipids, prior to the freezing-thawing process, showed better motility and viability than sperm incubated with liposomes made from fresh sperm head plasma membranes. These two types of liposomes were, however, less effective than egg yolk alone (He et al. 2001). Stallion spermatozoa were also studied, and as was shown for bull sperm (Graham et al. 1987), phosphatidylserine:cholesterol liposomes improved the recovery of motile cells after cryopreservation (Wilhelm et al. 1996). In a recent study, liposomes made from commercially available mixture of egg yolk lecithins (mainly phosphatidylcholine and phosphatidylethanolamine), named E80-liposomes, and used at $4 \%$ were efficient in preserving post-thaw motility. Furthermore, artificial inseminations performed with semen frozen with either E80-liposomes or the classical egg yolk extender gave 55 and $68 \%$ fertility rates respectively $(P=0.23)$, thus making these liposomes a promising alternative to replace egg yolk (Pillet et al. 2012). The use of liposomes to replace egg yolk in the classical cryopreservation extenders is still not routinely feasible for animal species. In humans, depending on the legislation, it is possible to use egg yolk, in combination with serum albumin, in the cryoconservation medium, but the main cryoprotectant remains glycerol, sometimes replaced by ethylene glycol, dimethyl sulfoxide, or 1,2-propanediol. Even though the egg yolk is certified virus-free and heat-inactivated at $56{ }^{\circ} \mathrm{C}$ for $30 \mathrm{~min}$, sanitary issues are still a concern. Attempts have been made to replace egg yolk with other lipids, but the literature is sparse on this point. Soy lecithin has however been shown to be efficient when combined with dimethyl sulfoxide and glycerol to maintain postthaw sperm motility (Jeyendran et al. 2008). This result was confirmed and soy lecithin was also shown to allow the maintenance of sperm cell morphology, binding capacity to hyaluronate in vitro, and DNA integrity in frozen-thawed human sperm (Reed et al. 2009).

\section{Incorporation of foreign material}

Large unilamellar immunoliposomes were used to transfect mouse RDM-4 lymphoma cells with a plasmid containing the Escherichia coli chloramphenicol acetyltransferase (CAT) gene under the control of a mammalian cAMP-regulated promoter (Wang \& Huang 1987). It thus seemed possible to try this process for sperm cell transformation, with the final goal of using spermatozoa as vectors for exogenous DNA, the so-called spermmediated gene transfer (SMGT). One of the first related attempts describes successful DNA transfer into mouse sperm, but no transgenic mice were obtained, although the fertilization frequency of oocytes remained normal (Bachiller et al. 1991). Pig sperm were transfected by DNA/liposome complexes encoding the destabilized enhanced green fluorescent protein (d2EGFP), then injected by ICSI into oocytes (Lai et al. 2001). The expression of d2EGFP started on day 3 of embryonic development, at the 2-cell to 4-cell stages. Transfer of ICSI embryos derived from sperm transfected by DNA/ liposome complex did not allow females to achieve pregnancies. The influence of DNA architecture on sperm transfection efficiency was studied using bovine spermatozoa (Hoelker et al. 2007). The insertion of a murine nontranscribed spacer (nts) in a plasmid encoding EGFP allowed a twofold to eightfold higher plasmid binding and uptake by spermatozoa. The presence of this sequence also increased the mean number of plasmids transmitted to 4-cell stage embryos. However, the percentage of blastocysts expressing EGFP remained very low $(3.6 \%)$, maybe indicating a low efficiency of the CMV promoter used here. The incorporation of exogenous DNA by equine spermatozoa was also shown to be enhanced by liposome-mediated transfection, but once again, the expression of the transfected protein, i.e. EGFP, was not detected in embryos obtained with transfected sperm (Ball et al. 2008).

The first report mentioning offspring obtained from liposome-transfected sperm cells, to our knowledge, concerns a marine species, the silver sea bream, Sparus sarba (Lu et al. 2002). These authors injected a liposome-transgene mixture (based on L-dioleoyl phosphatidylethanolamine) directly into the male gonads at least $48 \mathrm{~h}$ before spawning. The expression of the transgene (rainbow trout $\mathrm{GH}$ ) was found in many of the transgenic fishes. Furthermore, several animals showed a significant growth enhancement compared with non-transgenic controls. The authors thus propose this gene transfer technology as very valuable for 
aquaculture. The same kind of experiments were performed on mammals, namely rabbits, which received injections into their testes of DNA complexed either to DMSO or to liposome-based transfection reagents (Tfx-50 reagent or Lipofectamine-2000, Shen et al. (2006)). With these two reagents, the obtained transgenic ratios were of 39.6 and $47.8 \%$ respectively. This ratio was calculated as the percentage of offspring showing expression of human tissue plasminogen activator mutant (htPAm, under the control of $\beta$-casein promoter) by means of PCR and Southern blotting. The functionality of the transgene was confirmed in the female rabbits by the presence of bioactive htPAm in their milk.

Liposomes thus represent an efficient way to transfect spermatozoa in vitro or in vivo, but data concerning the production of transgenic offspring expressing the encoded protein remain scarce. Other transfection methods have been tried with different levels of efficiency, and lately nanopolymers have been proven as more efficient than liposomes in transfecting plasmids into bovine spermatozoa (Campos et al. 2011). It seems that the SMGT strategy remains promising in order to easily obtain transgenic animals.

\section{Regulation of sperm functions}

It has been known since 1951 that spermatozoa have to undergo final maturation steps in the female genital tract in order to be able to recognize, penetrate, and fertilize the oocyte. These maturational events are grouped under the term capacitation (Chang 1951, Austin 1952). The lipid composition of the sperm plasma membrane and mainly its cholesterol content are regulators of these maturational events (reviewed by Travis \& Kopf (2002)). Cholesterol-containing suspensions inhibited the fertilizing capacity of uterine-capacitated rabbit spermatozoa, a property that was conserved when cholesterol was dispersed into liposomes (Davis 1980). This author also showed that egg-lecithin liposomes had a facilitating effect on the induction of rat sperm $A R$, thus suggesting that capacitation was stimulated. These results were confirmed a few years later as cholesterol-bearing liposomes provoked decapacitation of rabbit sperm cells, suppressing their fertilizing capacity (Davis \& Davis 1983). These authors suggested that the transfer of cholesterol from liposomes to sperm plasma membranes was the antifusigen event limiting capacitation, revealed by stimulated AR. Using phosphatidylcholine/phosphatidylethanolamine liposomes containing cholesterol or not, it was clearly demonstrated that cholesterol could efflux the bovine sperm plasma membrane and that this loss of cholesterol was an early step in capacitation, measured by lysophosphatidylcholine-induced AR (Ehrenwald et al. 1988). This loss of sperm plasma membrane cholesterol is now a recognized early event triggering the capacitation process of mammalian spermatozoa.
In bovines, a great amount of work was conducted to understand the functions of particular proteins, the binder of sperm (BSP) protein family, in relation to lipid efflux during capacitation. Bovine seminal plasma contains three similar proteins secreted by the seminal vesicles and which bind to sperm surface upon ejaculation (Manjunath et al. 2009). In these studies, liposomes were largely used to understand the binding properties of the BSPs on the sperm membrane lipid moieties, as well as the consequences of this binding on lipid efflux. When the binding of BSP was tested on different phospholipid liposomes, it was found that BSPs only bind the phospholipids containing the phosphorylcholine group (Desnoyers \& Manjunath 1992). This specific phosphatidylcholine binding is an essential element of bovine sperm capacitation as measured by LPC-induced AR (Therien et al. 1995). The group of Manjunath has extensively studied the BSP properties, using liposomes as tools, and they have shown that BSP could modulate the process of capacitation induced by heparin, high-density lipoproteins, and Apo-Al-liposomes (Therien et al. 1997). More recently, they studied the interaction of BSP1 with model membranes and demonstrated that this protein induced local curvature of lipid membranes that may be involved in lipid domain formation and extraction of some lipids during capacitation (Lafleur et al. 2010). BSP homologous genes have recently been identified in the epididymis of humans (BSPH1) and mice (Bsph1 and Bsph2). BSPH1 showed binding properties to sperm cells similar to the BSP (Lefebvre et al. 2009) and murine epididymal BSPH1 also (Plante et al. 2012), thus suggesting that human and mouse epididymal proteins share properties with the BSP proteins secreted by the seminal vesicles of ungulates, probably playing similar roles in sperm functions.

The major protein present in bovine seminal plasma (which accounts for over $80 \%$ of the total proteins), PDC-109 (also named BSP1, Manjunath et al. (2009)), is produced by the seminal vesicles, and, upon ejaculation, binds bovine sperm. It has phosphorylcholine- and heparin-binding properties that modulate sperm capacitation. As for BSP, liposomes were also used to characterize the phospholipid-dependent binding capacity of this protein. The binding of PDC-109 to unilamellar vesicles was reduced when phosphatidylethanolamine or phosphatidylserine was incorporated into phosphatidylcholine vesicles (Muller et al. 1998). These authors also showed, using electron spin resonance (ESR), that the binding of PDC-109 to phosphatidylcholine vesicles provoked a rigidification of these membrane structures, suggesting a putative decapacitation function of the protein, that would be relieved by interaction with heparin-like glycosaminoglycans in the female genital tract. The membrane destabilization property of PDC-109 was demonstrated using DMPC vesicles that were disrupted when the protein was added, and this process was inhibited by cholesterol in 
a concentration-dependent manner, suggesting a role of PDC-109 in sperm membrane structural changes during capacitation (Gasset et al. 2000). This result was confirmed both on lipid vesicles and on bovine sperm as the mobility of spin-labeled phospholipids inserted in these membranes, measured by ESR, was reduced in the presence of the protein (Greube et al. 2001). The action of PDC-109 on membranes is due to the extraction of phospholipids with a phosphorylcholine head group in the outer leaflet, as shown on human erythrocytes and bovine epididymal spermatozoa (Tannert et al. 2007). More recently, the interaction of PDC-109 with cholesterol was investigated by following the dynamics of fluorescent cholesterol analogs in large unilamellar vesicles. It was shown that PDC-109 lowered the rotational mobility of cholesterol, dependent on the cholesterol structure (as esterification significantly reduced the observed effects of PDC-109), and the interaction was probably related to a cholesterol recognition/interaction amino acid consensus (CRAC) domain in the protein (Scolari et al. 2010). The use of lipid vesicles was thus an efficient tool to characterize the interactions between the major bovine seminal plasma proteins and their functions in the capacitation process. Recent studies have provided evidence that such mechanisms could be present in mice and humans, with orthologous proteins, and that further studies will be necessary to better understand the lipid-dependent regulation of this important step in the fertilization process.

The success of the following steps of the fertilization process is highly dependent on the quality of the capacitation. The lipid membrane changes mentioned above prepare the sperm cells to recognize the ZP, undergo the $A R$, and penetrate the $Z P$ to finally fuse with the oocyte plasma membrane. Liposomes have been used as valuable tools, as was the case for capacitation, to better understand which lipid moieties were fundamental in these last steps and their dynamics. The effect of liposomes made with phosphatidylcholine containing fatty acyl chains of either 10 (PC10) or 12 (PC12) carbons was studied on bull spermatozoa. After an incubation period of $15 \mathrm{~min}$, over $90 \%$ of the sperm cells had undergone an AR with both types of liposomes. Liposomes with fatty acyl chains composed of a number of carbons equal or greater than 14 had no effect on the AR. The percentage of penetrated zona-free hamster eggs varied with the concentration of PC12 liposomes, with better effects at 20 and $30 \mu \mathrm{M}$, leading to the possibility of using this PC12-dependent AR as a test to assess male fertility (Graham et al. 1986). These liposomes showed similar effects on ram and stallion spermatozoa whereas they were ineffective on boar spermatozoa under the same conditions (Graham et al. 1987). The same team studied the correlation between PC12-induced AR and the efficiency of zona-free hamster egg penetration using fresh and cryopreserved bull spermatozoa. In both cases, this test was proposed to be a good way to estimate the fertility of an individual as it was also correlated with female non-return rates (Graham \& Foote 1987, Graham et al. 1987). Incubating ram spermatozoa, punctured in different epididymal regions, with PC12 liposomes induced different levels of $A R$, increasing from the caput epididymidis where it was null to the cauda epididymidis, thus showing that the epididymal maturation steps were fundamental for the capacity of spermatozoa to penetrate the egg.

Liposomes were also used as targets to study the membrane fusion events occurring during the fertilization process. Fluorescently labelled liposomes were shown to fuse with cryopreserved bovine sperm before the occurrence of the $A R$, with the fluorescence being located in all sperm membrane domains. Fresh bovine and human spermatozoa only fused with liposomes if they had undergone their AR and showed a restriction of the fluorescence to the equatorial segment (ES). The fusion was $\mathrm{pH}$-dependent and was also related to the presence of particular lipids in the liposome composition, such as cardiolipin or phosphatidylserine. It thus appeared that the ES was the primary site involved in sperm-oocyte membrane fusion and that liposomes were appropriate tools to study this phenomenon (Arts et al. 1993). Using this tool, the same group showed that the ES contained specific sites for liposomal binding and that a barrier to lateral lipid diffusion was probably present in the ES membrane. This barrier was suggested to encompass both membrane leaflets as liposomes containing specific inner leaflet fluorescent probes still gave the same ES labeling pattern after incubation with spermatozoa (Arts et al. 1994). The fusion between liposomes and the ES was mediated by sperm protein(s) as it was sensitive to protease treatment (Arts et al. 1997). Unfortunately, no further data are available to characterize this interaction between the ES and liposomes as a model of membrane fusion during fertilization. The ES is a critical region of the spermatozoa for the success of fertilization, and it was very recently shown that the protein IZUMO1, necessary for sperm-egg fusion, is dynamically relocated in the ES after the AR (Satouh et al. 2012). Fertilin and cyritestin are members of the ADAM family and their disintegrin domains mediate sperm-egg binding. Their role in sperm-egg binding was studied using liposomes: it was shown that liposomes bearing 80 copies of fertilin peptide per outer membrane are 100-fold improved inhibitors of fertilization compared with linear peptides (Gupta \& Sampson 2001). However, the same group demonstrated that liposomes physically block the access of the sperm to the egg membrane, thereby preventing sperm binding to all egg receptors not just the fertilin- $\beta$ receptor.

Overall, liposomes were used to characterize different aspects of sperm-egg interaction and fusion and also as tools to determine the fertilizing potential of bovine spermatozoa in order to ameliorate the breeding of this species. It seems that the interest in studying sperm 
physiology with these lipid vesicles has decreased as the number of publications is scarce in the last 10 years.

\section{Ion channel characterization}

A few articles relate the use of liposomal structures to study the electrical properties of sperm ionic channels. Liposomes containing boar sperm plasma membrane proteins were produced to study calcium-conducting channels, leading to the characterization of such channels as prominent components of mammalian sperm plasma membranes (Cox \& Peterson 1989). This paper was one of the first articles showing calcium current in a mammalian sperm channel, previous work on this topic had been done on sea urchins. The importance of calcium in sperm cell physiology has since been well recognized and characterized. Another paper reports patch-clamp studies on human sperm chloride channels that were reassembled in giant liposomes made from sperm membrane protein extracts. This work described the conductance properties of three distinct types of chloride channels inside human sperm membranes (Bai \& Shi 2001). Even though their roles in regulating fertilization are of primary importance, sperm ion channels remain poorly understood due to the extreme difficulty in application of the patch-clamp technique to spermatozoa. New data have recently become available due to a recent progress in the methodology to study sperm ion channels, a reproducible whole-cell patch-clamp technique for mouse and human cells (reviewed by Kirichok \& Lishko (2011)).

\section{Conclusion}

Fertility is related to the encounter and fusion of two properly matured gametes. The maturation of sperm cells is a long multi-step biological process as the male gamete, when released from the seminiferous epithelium in the testis, is not able to naturally fertilize an oocyte. This process demands modification of their metabolism, their membrane and intracellular structures, and their biochemical composition. One of the key actors in posttesticular sperm maturation is represented by several types of lipid vesicles secreted by the epithelium of the male reproductive tract glands, interacting sequentially with the gametes, namely the epididymosomes and the prostasomes. These vesicles allow the acquisition of a particular protein pattern and a lipid composition that are fundamental for the steps of gamete recognition and fusion. The study of the molecular processes driving the vesicle-dependent maturation of spermatozoa is difficult due to the particular structure of the organs involved, particularly the epididymis, and the difficulty in obtaining efficient animal models. However, studying these events is undoubtedly of great interest as future discoveries may be very promising in order to better understand cases of unexplained male infertility or to provide new insights leading to the development of male contraception.

\section{Declaration of interest}

The authors declare that there is no conflict of interest that could be perceived as prejudicing the impartiality of the review reported.

\section{Funding}

The work from the authors' laboratories described in this review has been supported by grants from the Canadian Institutes for Health Research, and the Natural Sciences and Engineering Research Council of Canada to R Sullivan.

\section{Acknowledgements}

The authors wish to acknowledge Dr Clemence Belleannee and Mrs Christine Legare for figure and table editing.

\section{References}

Aalberts M, Sostaric E, Wubbolts R, Wauben MW, Nolte-'t Hoen EN, Gadella BM, Stout TA \& Stoorvogel W 2012a Spermatozoa recruit prostasomes in response to capacitation induction. Biochimica et Biophysica Acta [in press]. (doi:10.1016/j.bbapap.2012.08.008)

Aalberts $M$, van Dissel-Emiliani FM, van Adrichem NP, van Wijnen $M$, Wauben MH, Stout TA \& Stoorvogel W 2012 $b$ Identification of distinct populations of prostasomes that differentially express prostate stem cell antigen, annexin A1, and GLIPR2 in humans. Biology of Reproduction 86 82. (doi:10.1095/biolreprod.111.095760)

Arienti G, Carlini E \& Palmerini CA 1997 Fusion of human sperm to prostasomes at acidic pH. Journal of Membrane Biology 155 89-94. (doi:10.1007/s002329900160)

Arienti G, Saccardi C, Carlini E, Verdacchi R \& Palmerini CA 1999 Distribution of lipid and protein in human semen fractions. Clinica Chimica Acta 289 111-120. (doi:10.1016/S0009-8981(99)00169-2)

Arts EG, Kuiken J, Jager S \& Hoekstra D 1993 Fusion of artificial membranes with mammalian spermatozoa. Specific involvement of the equatorial segment after acrosome reaction. European Journal of Biochemistry 217 1001-1009. (doi:10.1111/j.1432-1033.1993.tb18 331.x)

Arts EG, Jager S \& Hoekstra D 1994 Evidence for the existence of lipiddiffusion barriers in the equatorial segment of human spermatozoa. Biochemical Journal 304 (Pt 1) 211-218.

Arts EG, Wijchman JG, Jager S \& Hoekstra D 1997 Protein involvement in the fusion between the equatorial segment of acrosome-reacted human spermatozoa and liposomes. Biochemical Journal 325 (Pt 1) 191-198.

Arvidson G, Ronquist G, Wikander G \& Ojteg AC 1989 Human prostasome membranes exhibit very high cholesterol/phospholipid ratios yielding high molecular ordering. Biochimica et Biophysica Acta 984 167-173. (doi:10.1016/0005-2736(89)90212-5)

Aumuller G, Renneberg H, Schiemann PJ, Wilhelm B, Seitz J, Konrad L \& Wennemuth G 1997 The role of apocrine released proteins in the post-testicular regulation of human sperm function. Advances in Experimental Medicine and Biology 424 193-219. (doi:10.1007/9781-4615-5913-9_39)

Aumuller G, Wilhelm B \& Seitz J 1999 Apocrine secretion - fact or artifact? Anatomischer Anzeiger 181 437-446. (doi:10.1016/SOREF10=10.1016/ S0940-9602(99)80020-X)

Austin CR 1952 The capacitation of the mammalian sperm. Nature $\mathbf{1 7 0}$ 326. (doi:10.1038/170326a0) 
Bachiller D, Schellander K, Peli J \& Ruther U 1991 Liposome-mediated DNA uptake by sperm cells. Molecular Reproduction and Development 30 194-200. (doi:10.1002/mrd.1080300305)

Bai JP \& Shi YL 2001 A patch-clamp study on human sperm $\mathrm{Cl}^{-}$channel reassembled into giant liposome. Asian Journal of Andrology 3 185-191.

Ball BA, Sabeur K \& Allen WR 2008 Liposome-mediated uptake of exogenous DNA by equine spermatozoa and applications in sperm-mediated gene transfer. Equine Veterinary Journal 40 76-82. (doi:10.2746/042516407X235786)

Bobrie A, Colombo M, Raposo G \& Thery C 2011 Exosome secretion: molecular mechanisms and roles in immune responses. Traffic $\mathbf{1 2}$ 1659-1668. (doi:10.1111/j.1600-0854.2011.01225.x)

Burden HP, Holmes CH, Persad R \& Whittington K 2006 Prostasomes their effects on human male reproduction and fertility. Human Reproduction Update 12 283-292. (doi:10.1093/humupd/dmi052)

Caballero J, Frenette G, D'Amours O, Belleannee C, Lacroix-Pepin N, Robert C \& Sullivan R 2012 Bovine sperm raft membrane associated glioma pathogenesis-related 1-like protein 1 (GliPr1L1) is modified during the epididymal transit and is potentially involved in sperm binding to the zona pellucida. Journal of Cellular Physiology 227 3876-3886. (doi:10.1002/jcp.24099)

Campos VF, de Leon PM, Komninou ER, Dellagostin OA, Deschamps JC, Seixas FK \& Collares T 2011 NanoSMGT: transgene transmission into bovine embryos using halloysite clay nanotubes or nanopolymer to improve transfection efficiency. Theriogenology 76 1552-1560. (doi:10.1016/j.theriogenology.2011.06.027)

Chabory E, Damon C, Lenoir A, Kauselmann G, Kern H, Zevnik B, Garrel C, Saez F, Cadet R, Henry-Berger J et al. 2009 Epididymis selenoindependent glutathione peroxidase 5 maintains sperm DNA integrity in mice. Journal of Clinical Investigation 119 2074-2085. (doi:10.1172/ JCl38940)

Chang MC 1951 Fertilizing capacity of spermatozoa deposited into the fallopian tubes. Nature 168 697-698. (doi:10.1038/168697b0)

Cooper TG 1998 Interactions between epididymal secretions and spermatozoa. Journal of Reproduction and Fertility. Supplement $\mathbf{5 3}$ 119-136.

Cox T \& Peterson RN 1989 Identification of calcium conducting channels in isolated boar sperm plasma membranes. Biochemical and Biophysical Research Communications 161 162-168. (doi:10.1016/0006-291X (89)91575-1)

D'Amours O, Bordeleau LJ, Frenette G, Blondin P, Leclerc P \& Sullivan R 2012a Binder of sperm 1 and epididymal sperm binding protein 1 are associated with different bull sperm subpopulations. Reproduction 143 759-771. (doi:10.1530/REP-11-0392)

D'Amours O, Frenette G, Bordeleau LJ, Allard N, Leclerc P, Blondin P \& Sullivan R 2012b Epididymosomes transfer epididymal sperm binding protein 1 (ELSPBP1) to dead spermatozoa during epididymal transit in bovine. Biology of Reproduction 87 94. (doi:10.1095/biolreprod.112. 100990)

Davis BK 1980 Interaction of lipids with the plasma membrane of sperm cells. I. The antifertilization action of cholesterol. Archives of Andrology 5 249-254. (doi:10.3109/01485018008986993)

Davis BK \& Davis NV 1983 Binding by glycoproteins of seminal plasma membrane vesicles accelerates decapacitation in rabbit spermatozoa. Biochimica et Biophysica Acta 727 70-76. (doi:10.1016/0005-2736 (83)90370-X)

De Leeuw FE, De Leeuw AM, Den Daas JH, Colenbrander B \& Verkleij AJ 1993 Effects of various cryoprotective agents and membrane-stabilizing compounds on bull sperm membrane integrity after cooling and freezing. Cryobiology 30 32-44. (doi:10.1006/cryo.1993.1005)

Desnoyers L \& Manjunath P 1992 Major proteins of bovine seminal plasma exhibit novel interactions with phospholipid. Journal of Biological Chemistry 267 10149-10155.

Ecroyd H, Sarradin P, Dacheux JL \& Gatti JL 2004 Compartmentalization of prion isoforms within the reproductive tract of the ram. Biology of Reproduction 71 993-1001. (doi:10.1095/biolreprod.104.029801)

Ehrenwald E, Parks JE \& Foote RH 1988 Cholesterol efflux from bovine sperm. I. Induction of the acrosome reaction with lysophosphatidylcholine after reducing sperm cholesterol. Gamete Research 20 145-157. (doi:10.1002/mrd.1120200205)

Eickhoff R, Wilhelm B, Renneberg H, Wennemuth G, Bacher M, Linder D, Bucala R, Seitz J \& Meinhardt A 2001 Purification and characterization of macrophage migration inhibitory factor as a secretory protein from rat epididymis: evidences for alternative release and transfer to spermatozoa. Molecular Medicine 7 27-35.

Eickhoff R, Baldauf C, Koyro HW, Wennemuth G, Suga Y, Seitz J, Henkel R \& Meinhardt A 2004 Influence of macrophage migration inhibitory factor (MIF) on the zinc content and redox state of protein-bound sulphydryl groups in rat sperm: indications for a new role of MIF in sperm maturation. Molecular Human Reproduction 10 605-611. (doi:10.1093/ molehr/gah075)

Eickhoff R, Jennemann G, Hoffbauer G, Schuring MP, Kaltner H, Sinowatz F, Gabius HJ \& Seitz J 2006 Immunohistochemical detection of macrophage migration inhibitory factor in fetal and adult bovine epididymis: release by the apocrine secretion mode? Cells, Tissues, Organs 182 22-31. (doi:10.1159/000091715)

Fabiani R, Johansson L, Lundkvist O \& Ronquist G 1995 Prolongation and improvement of prostasome promotive effect on sperm forward motility. European Journal of Obstetrics, Gynecology, and Reproductive Biology 58 191-198. (doi:10.1016/0028-2243(95)80022-K)

Fornes MW, Barbieri A \& Cavicchia JC 1995a Morphological and enzymatic study of membrane-bound vesicles from the lumen of the rat epididymis. Andrologia 27 1-5. (doi:10.1111/j.1439-027REF39=10. 1095/biolreprod67.1.308)

Fornes MW, Sosa MA, Bertini F \& Burgos MH 1995b Vesicles in rat epididymal fluid. Existence of two populations differing in ultrastructure and enzymatic composition. Andrologia 27 233-237. (doi:10.1111/j. 1439-0272.1995.tb01099.x)

Fraile B, Martin R, De Miguel MP, Arenas MI, Bethencourt FR, Peinado F, Paniagua R \& Santamaria L 1996 Light and electron microscopic immunohistochemical localization of protein gene product 9.5 and ubiquitin immunoreactivities in the human epididymis and vas deferens. Biology of Reproduction 55 291-297. (doi:10.1095/biolreprod55.2.291)

Frenette G \& Sullivan R 2001 Prostasome-like particles are involved in the transfer of P25b from the bovine epididymal fluid to the sperm surface. Molecular Reproduction and Development 59 115-121. (doi:10.1002/ mrd.1013)

Frenette G, Lessard C \& Sullivan R 2002 Selected proteins of "prostasomelike particles" from epididymal cauda fluid are transferred to epididymal caput spermatozoa in bull. Biology of Reproduction 67 308-313. (doi:10.1095/biolreprod67.1.308)

Frenette G, Lessard C, Madore E, Fortier MA \& Sullivan R 2003 Aldose reductase and macrophage migration inhibitory factor are associated with epididymosomes and spermatozoa in the bovine epididymis. Biology of Reproduction 69 1586-1592. (doi:10.1095/biolreprod.103. 019216)

Frenette G, Lessard C \& Sullivan R 2004 Polyol pathway along the bovine epididymis. Molecular Reproduction and Development 69 448-456. (doi:10.1002/mrd.20170)

Frenette G, Legare C, Saez F \& Sullivan R 2005 Macrophage migration inhibitory factor in the human epididymis and semen. Molecular Human Reproduction 11 575-582. (doi:10.1093/molehr/gah197)

Frenette G, Girouard J \& Sullivan R 2006 Comparison between epididymosomes collected in the intraluminal compartment of the bovine caput and cauda epididymidis. Biology of Reproduction $\mathbf{7 5}$ 885-890. (doi:10.1095/biolreprod. 106.054692)

Frenette G, Girouard J, D'Amours O, Allard N, Tessier L \& Sullivan R 2010 Characterization of two distinct populations of epididymosomes collected in the intraluminal compartment of the bovine cauda epididymis. Biology of Reproduction 83 473-480. (doi:10.1095/ biolreprod.109.082438)

Gasset M, Magdaleno L \& Calvete JJ 2000 Biophysical study of the perturbation of model membrane structure caused by seminal plasma protein PDC-109. Archives of Biochemistry and Biophysics 374 241-247. (doi:10.1006/abbi.1999.1593)

Gatti JL, Castella S, Dacheux F, Ecroyd H, Metayer S, Thimon V \& Dacheux JL 2004 Post-testicular sperm environment and fertility. Animal Reproduction Science 82-83 321-339. (doi:10.1016/j.anireprosci.2004. 05.011)

Gatti JL, Metayer S, Belghazi M, Dacheux F \& Dacheux JL 2005 Identification, proteomic profiling, and origin of ram epididymal fluid exosome-like vesicles. Biology of Reproduction 2 1452-1465. (doi:10. 1095/biolreprod.104.036426) 
Gibbs GM, Roelants K \& O'Bryan MK 2008 The CAP superfamily: cysteinerich secretory proteins, antigen 5 , and pathogenesis-related 1 proteins roles in reproduction, cancer, and immune defense. Endocrine Reviews 29 865-897. (doi:10.1210/er.2008-0032)

Gibbs GM, Lo JC, Nixon B, Jamsai D, O'Connor AE, Rijal S, Sanchez-Partida LG, Hearn MT, Bianco DM \& O'Bryan MK 2010 Glioma pathogenesis-related 1-like 1 is testis enriched, dynamically modified, and redistributed during male germ cell maturation and has a potential role in sperm-oocyte binding. Endocrinology 151 2331-2342. (doi:10.1210/en.2009-1255)

Girouard J, Frenette G \& Sullivan R 2009 Compartmentalization of proteins in epididymosomes coordinates the association of epididymal proteins with the different functional structures of bovine spermatozoa. Biology of Reproduction 80 965-972. (doi:10.1095/biolreprod.108. 073551)

Girouard J, Frenette G \& Sullivan R 2011 Comparative proteome and lipid profiles of bovine epididymosomes collected in the intraluminal compartment of the caput and cauda epididymidis. International Journal of Andrology 34 e475-e486. (doi:10.1111/j.1365-2605.2011. 01203.x)

Graham JK \& Foote RH 1987 Dilauroylphosphatidylcholine liposome effects on the acrosome reaction and in vitro penetration of zona-free hamster eggs by bull sperm: I. A fertility assay for fresh semen. Gamete Research 16 133-145. (doi:10.1002/mrd.1120160205)

Graham JK, Foote RH \& Parrish JJ 1986 Effect of dilauroylphosphatidylcholine on the acrosome reaction and subsequent penetration of bull spermatozoa into zona-free hamster eggs. Biology of Reproduction 35 413-424. (doi:10.1095/biolreprod35.2.413)

Graham JK, Foote RH \& Hough SR 1987 Penetration of zona-free hamster eggs by liposome-treated sperm from the bull, ram, stallion, and boar. Biology of Reproduction 37 181-188. (doi:10.1095/biolreprod37. 1 REF49=10.1210/en.2009-1255)

Greube A, Muller K, Topfer-Petersen E, Herrmann A \& Muller P 2001 Influence of the bovine seminal plasma protein PDC-109 on the physical state of membranes. Biochemistry 40 8326-8334. (doi:10.1021/ bi010552+)

Griffiths GS, Galileo DS, Reese K \& Martin-Deleon PA 2008 Investigating the role of murine epididymosomes and uterosomes in GPI-linked protein transfer to sperm using SPAM1 as a model. Molecular Reproduction and Development 75 1627-1636. (doi:10.1002/mrd. 20907)

Grimalt P, Bertini F \& Fornes MW 2000 High-affinity sites for $\beta$-Dgalactosidase on membrane-bound vesicles isolated from rat epididymal fluid. Archives of Andrology 44 85-91. (doi:10.1080/014850100 262245)

Groos S, Wilhelm B, Renneberg H, Riva A, Reichelt R, Seitz J \& Aumuller G 1999 Simultaneous apocrine and merocrine secretion in the rat coagulating gland. Cell and Tissue Research 295 495-504. (doi:10.1007/ s004410051255)

Gupta S \& Sampson NS 2001 Dimyristoylated peptides incorporated into liposomes are polyvalent fertilin beta mimics. Organic Letters 3 3333-3335. (doi:10.1021/ol016573d)

He L, Bailey JL \& Buhr MM 2001 Incorporating lipids into boar sperm decreases chilling sensitivity but not capacitation potential. Biology of Reproduction 64 69-79. (doi:10.1095/biolreprod64.1.69)

Hermo L \& Jacks D 2002 Nature's ingenuity: bypassing the classical secretory route via apocrine secretion. Molecular Reproduction and Development 63 394-410. (doi:10.1002/mrd.90023)

Hoelker M, Mekchay S, Schneider H, Bracket BG, Tesfaye D, Jennen D, Tholen E, Gilles M, Rings F, Griese J et al. 2007 Quantification of DNA binding, uptake, transmission and expression in bovine sperm mediated gene transfer by RT-PCR: effect of transfection reagent and DNA architecture. Theriogenology 67 1097-1107. (doi:10.1016/j.theriogenology.2006.12.011)

Holt WV \& North RD 1988 The role of membrane-active lipids in the protection of ram spermatozoa during cooling and storage. Gamete Research 19 77-89. (doi:10.1002/mrd.1120190108)

Jeyendran RS, Acosta VC, Land S \& Coulam CB 2008 Cryopreservation of human sperm in a lecithin-supplemented freezing medium. Fertility and Sterility 90 1263-1265. (doi:10.1016/j.fertnstert.2007.10.068)
Johnston DS, Jelinsky SA, Bang HJ, Dicandeloro P, Wilson E, Kopf GS \& Turner TT 2005 The mouse epididymal transcriptome: transcriptional profiling of segmental gene expression in the epididymis. Biology of Reproduction 73 404-413. (doi:10.1095/biolreprod.105.039719)

Johnston DS, Turner TT, Finger JN, Owtscharuk TL, Kopf GS \& Jelinsky SA 2007 Identification of epididymis-specific transcripts in the mouse and rat by transcriptional profiling. Asian Journal of Andrology 9 522-527. (doi:10.1111/j.1745-7262.2007.00317.x)

Jones R 1998 Plasma membrane structure and remodelling during sperm maturation in the epididymis. Journal of Reproduction and Fertility. Supplement 53 73-84.

Jones R, Mann T \& Sherins RJ 1978 Adverse effects of peroxidized lipid on human spermatozoa. Proceedings of the Royal Society of London B Biological Sciences 201 413-417.

Joshi CS, Suryawanshi AR, Khan SA, Balasinor NH \& Khole VV 2012 Liprin a3: a putative estrogen regulated acrosomal protein. Histochemistry and Cell Biology 139 535-548. (doi:10.1007/s00418-012-1044-y)

Kirchhoff C 1996 CD52 is the 'major maturation-associated' sperm membrane antigen. Molecular Human Reproduction 2 9-17. (doi:10. 1093/molehr/2.1.9)

Kirchhoff C 1998 Molecular characterization of epididymal proteins. Reviews of Reproduction 3 86-95. (doi:10.1530/ror.0.0030086)

Kirchhoff C 1999 Gene expression in the epididymis. International Review of Cytology 188 133-202.

Kirchhoff C \& Hale G 1996 Cell-to-cell transfer of glycosylphosphatidylinositol-anchored membrane proteins during sperm maturation. Molecular Human Reproduction 2 177-184. (doi:10.1093/molehr/ 2.3.177)

Kirichok Y \& Lishko PV 2011 Rediscovering sperm ion channels with the patch-clamp technique. Molecular Human Reproduction 17 478-499. (doi:10.1093/molehr/gar044)

Krapf D, Ruan YC, Wertheimer EV, Battistone MA, Pawlak JB, Sanjay A, Pilder SH, Cuasnicu P, Breton S \& Viscontic PE 2012 Src is necessary for epididymal development and is incorporated into sperm during epididymal transit. Developmental Biology 369 43-53. (doi:10.1016/j. ydbio.2012.06.017)

Lafleur M, Courtemanche L, Karlsson G, Edwards K, Schwartz JL \& Manjunath P 2010 Bovine binder-of-sperm protein BSP1 promotes protrusion and nanotube formation from liposomes. Biochemical and Biophysical Research Communications 399 406-411. (doi:10.1016/j. bbrc.2010.07.088)

Lai L, Sun Q, Wu G, Murphy CN, Kuhholzer B, Park KW, Bonk AJ, Day BN \& Prather RS 2001 Development of porcine embryos and offspring after intracytoplasmic sperm injection with liposome transfected or nontransfected sperm into in vitro matured oocytes. Zygote 9 339-346. (doi:10.1017/S0967199401001393)

Lefebvre J, Boileau G \& Manjunath P 2009 Recombinant expression and affinity purification of a novel epididymal human sperm-binding protein BSPH1. Molecular Human Reproduction 15 105-114. (doi:10.1093/ molehr/gan077)

Legare C, Berube B, Boue F, Lefievre L, Morales CR, El-Alfy M \& Sullivan R 1999 Hamster sperm antigen P26h is a phosphatidylinositol-anchored protein. Molecular Reproduction and Development 52 225-233. (doi:10.1002/(SICl)1098-2795(199902)52:2 <225::AID-MRD14>3.0. CO;2-M)

Lu JK, Fu BH, Wu JL \& Chen TT 2002 Production of transgenic silver sea bream (Sparus sarba) by different gene transfer methods. Marine Biotechnology 4 328-337. (doi:10.1007/s10126-002-0027-8)

Manin M, Lecher P, Martinez A, Tournadre S \& Jean C 1995 Exportation of mouse vas deferens protein, a protein without a signal peptide, from mouse vas deferens epithelium: a model of apocrine secretion. Biology of Reproduction 52 50-62. (doi:10.1095/biolreprod52.1.50)

Manjunath P, Lefebvre J, Jois PS, Fan J \& Wright MW 2009 New nomenclature for mammalian BSP genes. Biology of Reproduction $\mathbf{8 0}$ 394-397. (doi:10.1095/biolreprod.108.074088)

Martin-DeLeon PA 2006 Epididymal SPAM1 and its impact on sperm function. Molecular and Cellular Endocrinology 250 114-121. (doi:10. 1016/j.mce.2005.12.033)

Mawson CA \& Fischer MI 1951 Zinc content of the genital organs of the rat. Nature 167 859. (doi:10.1038/167859a0) 
Moraes EA, Graham JK, Torres CA, Meyers M \& Spizziri B 2010 Delivering cholesterol or cholestanol to bull sperm membranes improves cryosurvival. Animal Reproduction Science 118 148-154. (doi:10.1016/ j.anireprosci.2009.08.002)

Muller P, Erlemann KR, Muller K, Calvete JJ, Topfer-Petersen E, Marienfeld K \& Herrmann A 1998 Biophysical characterization of the interaction of bovine seminal plasma protein PDC-109 with phospholipid vesicles. European Biophysics Journal 27 33-41. (doi:10.1007/ s002490050108)

Nickel W 2003 The mystery of nonclassical protein secretion. A current view on cargo proteins and potential export routes. European Journal of Biochemistry 270 2109-2119. (doi:10.1046/j.1432-1033.2003.03577.x)

Oh J, Woo JM, Choi E, Kim T, Cho BN, Park ZY, Kim YC, Kim DH \& Cho C 2005 Molecular, biochemical, and cellular characterization of epididymal ADAMs, ADAM7 and ADAM28. Biochemical and Biophysical Research Communications 331 1374-1383. (doi:10.1016/j.bbrc.2005.04.067)

Oh JS, Han C \& Cho C 2009 ADAM7 is associated with epididymosomes and integrated into sperm plasma membrane. Molecules and Cells $\mathbf{2 8}$ 441-446. (doi:10.1007/s10059-009-0140-x)

Ollero M, Blanco TM, Lopez-Perez MJ \& Cebrian Perez JA 1996 Surface changes associated with ram sperm cryopreservation revealed by counter-current distribution in an aqueous two-phase system. Effect of different cryoprotectants. Journal of Chromatography. B, Biomedical Applications 680 157-164. (doi:10.1016/0378-4347(95)00461-0)

Pillet E, Labbe C, Batellier F, Duchamp G, Beaumal V, Anton M, Desherces S, Schmitt E \& Magistrini M 2012 Liposomes as an alternative to egg yolk in stallion freezing extender. Theriogenology 77 268-279. (doi:10.1016/j.theriogenology.2011.08.001)

Plante G, Therien I \& Manjunath P 2012 Characterization of recombinant murine binder of sperm protein homolog 1 and its role in capacitation. Biology of Reproduction 87 20, 1-11. (doi:10.1095/biolreprod.111. 096644)

Poliakov A, Spilman M, Dokland T, Amling CL \& Mobley JA 2009 Structural heterogeneity and protein composition of exosome-like vesicles (prostasomes) in human semen. Prostate 69 159-167. (doi:10.1002/ pros.20860)

Pons-Rejraji H, Artonne C, Sion B, Brugnon F, Canis M, Janny L \& Grizard G 2011 Prostasomes: inhibitors of capacitation and modulators of cellular signalling in human sperm. International Journal of Andrology 34 568-580. (doi:10.1111/j.1365-2605.2010.01116.x)

Quinn PJ, Chow PY \& White IG 1980 Evidence that phospholipid protects ram spermatozoa from cold shock at a plasma membrane site. Journal of Reproduction and Fertility 60 403-407. (doi:10.1530/jrf.0.0600403)

Reed ML, Ezeh PC, Hamic A, Thompson DJ \& Caperton CL 2009 Soy lecithin replaces egg yolk for cryopreservation of human sperm without adversely affecting postthaw motility, morphology, sperm DNA integrity, or sperm binding to hyaluronate. Fertility and Sterility 92 1787-1790. (doi:10.1016/j.fertnstert.2009.05.026)

Rejraji H, Vernet P \& DrevetG JR 2002 GPX5 is present in the mouse caput and cauda epididymidis lumen at three different locations. Molecular Reproduction and Development 63 96-103. (doi:10.1002/mrd.10136)

Rejraji H, Sion B, Prensier G, Carreras M, Motta C, Frenoux JM, Vericel E, Grizard G, Vernet P \& Drevet JR 2006 Lipid remodeling of murine epididymosomes and spermatozoa during epididymal maturation. Biology of Reproduction 74 1104-1113. (doi:10.1095/biolreprod.105. 049304)

Robaire B \& Viger RS 1995 Regulation of epididymal epithelial cell functions. Biology of Reproduction 52 226-236. (doi:10.1095/biolreprod52.2.226)

Ronquist G 2012 Prostasomes are mediators of intercellular communication: from basic research to clinical implications. Journal of Internal Medicine 271 400-413. (doi:10.1111/j.1365-2796.2011.02487.x)

Ronquist G \& Brody I 1985 The prostasome: its secretion and function in man. Biochimica et Biophysica Acta 822 203-218. (doi:10.1016/03044157(85)90008-5)

Ronquist G \& Hedstrom M 1977 Restoration of detergent-inactivated adenosine triphosphatase activity of human prostatic fluid with concanavalin A. Biochimica et Biophysica Acta 483 483-486. (doi:10.1016/ 0005-2744(77)90078-X)

Ronquist G, Brody I, Gottfries A \& Stegmayr B $1978 \mathrm{An} \mathrm{Mg}^{2+}$ and $\mathrm{Ca}^{2+}$. stimulated adenosine triphosphatase in human prostatic fluid-part II. Andrologia 10 427-433. (doi:10.1111/j.1439-0272.1978.tb03064.x)
Ronquist G, Nilsson BO \& Hjerten S 1990 Interaction between prostasomes and spermatozoa from human semen. Archives of Andrology $\mathbf{2 4}$ 147-157. (doi:10.3109/01485019008986874)

Ropke T, Oldenhof H, Leiding C, Sieme H, Bollwein H \& Wolkers WF 2011 Liposomes for cryopreservation of bovine sperm. Theriogenology $\mathbf{7 6}$ 1465-1472. (doi:10.1016/j.theriogenology.2011.06.015)

Saez F, Frenette G \& Sullivan R 2003 Epididymosomes and prostasomes: their roles in posttesticular maturation of the sperm cells. Journal of Andrology 24 149-154. (doi:10.1002/j.1939-4640.2003.tb02653.x)

Sahlen GE, Egevad L, Ahlander A, Norlen BJ, Ronquist G \& Nilsson BO 2002 Ultrastructure of the secretion of prostasomes from benign and malignant epithelial cells in the prostate. Prostate 53 192-199. (doi:10.1002/pros.10126)

Satouh Y, Inoue N, Ikawa M \& Okabe M 2012 Visualization of the moment of mouse sperm-egg fusion and dynamic localization of IZUMO1. Journal of Cell Science 125 4985-4990. (doi:10.1242/jcs.100867)

Scolari S, Muller K, Bittman R, Herrmann A \& Muller P 2010 Interaction of mammalian seminal plasma protein PDC-109 with cholesterol: implications for a putative CRAC domain. Biochemistry 49 9027-9031. (doi:10.1021/bi101257c)

Sengupta P, Baird B \& Holowka D 2007 Lipid rafts, fluid/fluid phase separation, and their relevance to plasma membrane structure and function. Seminars in Cell \& Developmental Biology 18 583-590. (doi:10.1016/j.semcdb.2007.07.010)

Shen W, Li L, Pan Q, Min L, Dong H \& Deng J 2006 Efficient and simple production of transgenic mice and rabbits using the new DMSO-sperm mediated exogenous DNA transfer method. Molecular Reproduction and Development 73 589-594. (doi:10.1002/mrd.20401)

Simons K \& Ikonen E 1997 Functional rafts in cell membranes. Nature 387 569-572. (doi:10.1038/42408)

Sullivan R 1999 Interaction between sperm and epididymal secretory proteins. In The Male Gamete: From Basic to Clinical Applications, pp 93-104. Ed. C Gagnon. Vienna: Cache River Press.

Sullivan R, Saez F, Girouard J \& Frenette G 2005 Role of exosomes in sperm maturation during the transit along the male reproductive tract. Blood Cells, Molecules \& Diseases 35 1-10. (doi:10.1016/j.bcmd.2005. 03.005)

Suryawanshi AR, Khan SA, Joshi CS \& Khole VV 2012 Epididymosomemediated acquisition of MMSDH, an androgen-dependent and developmentally regulated epididymal sperm protein. Journal of Andrology 33 963-974. (doi:10.2164/jandrol.111.014753)

Sutovsky P, Moreno R, Ramalho-Santos J, Dominko T, Thompson WE \& Schatten G 2001 A putative, ubiquitin-dependent mechanism for the recognition and elimination of defective spermatozoa in the mammalian epididymis. Journal of Cell Science 114 1665-1675.

Tannert A, Kurz A, Erlemann KR, Muller K, Herrmann A, Schiller J, Topfer-Petersen E, Manjunath P \& Muller P 2007 The bovine seminal plasma protein PDC-109 extracts phosphorylcholine-containing lipids from the outer membrane leaflet. European Biophysics Journal 36 461-475. (doi:10.1007/s00249-006-0105-3)

Therien I, Bleau G \& Manjunath P 1995 Phosphatidylcholine-binding proteins of bovine seminal plasma modulate capacitation of spermatozoa by heparin. Biology of Reproduction 52 1372-1379. (doi:10.1095/ biolreprod52.6.1372)

Therien I, Soubeyrand S \& Manjunath P 1997 Major proteins of bovine seminal plasma modulate sperm capacitation by high-density lipoprotein. Biology of Reproduction 57 1080-1088. (doi:10.1095/biolreprod57.5.1080)

Thery C 2011 Exosomes: secreted vesicles and intercellular communications. F1000 Biology Reports 3 15. (doi:10.3410/B3-15)

Thimon V, Koukoui O, Calvo E \& Sullivan R 2007 Region-specific gene expression profiling along the human epididymis. Molecular Human Reproduction 13 691-704. (doi:10.1093/molehr/gam051)

Thimon V, Calvo E, Koukoui O, Legare C \& Sullivan R 2008a Effects of vasectomy on gene expression profiling along the human epididymis. Biology of Reproduction 79 262-273. (doi:10.1095/biolreprod.107. 066449)

Thimon V, Frenette G, Saez F, Thabet M \& Sullivan R 2008b Protein composition of human epididymosomes collected during surgical vasectomy reversal: a proteomic and genomic approach. Human Reproduction 23 1698-1707. (doi:10.1093/humrep/den181) 
Travis AJ \& Kopf GS 2002 The role of cholesterol efflux in regulating the fertilization potential of mammalian spermatozoa. Journal of Clinical Investigation 110 731-736. (doi:10.1172/JCl16392)

Utleg AG, Yi EC, Xie T, Shannon P, White JT, Goodlett DR, Hood L \& Lin B 2003 Proteomic analysis of human prostasomes. Prostate 56 150-161. (doi:10.1002/pros.10255)

Wang CY \& Huang L 1987 pH-sensitive immunoliposomes mediate targetcell-specific delivery and controlled expression of a foreign gene in mouse. PNAS 84 7851-7855. (doi:10.1073/pnas.84.22.7851)

Wilhelm KM, Graham JK \& Squires EL 1996 Effects of phosphatidylserine and cholesterol liposomes on the viability, motility, and acrosomal integrity of stallion spermatozoa prior to and after cryopreservation. Cryobiology 33 320-329. (doi:10.1006/cryo.1996.0032)
Yanagimachi R, Kamiguchi Y, Mikamo K, Suzuki F \& Yanagimachi H 1985 Maturation of spermatozoa in the epididymis of the Chinese hamster. American Journal of Anatomy 172 317-330. (doi:10.1002/aja.1001720406)

Zeron Y, Tomczak M, Crowe J \& Arav A 2002 The effect of liposomes on thermotropic membrane phase transitions of bovine spermatozoa and oocytes: implications for reducing chilling sensitivity. Cryobiology 45 143-152. (doi:10.1016/S0011-2240(02)00123-2)

Received 15 February 2013

First decision 20 March 2013

Accepted 22 April 2013 